\title{
COMMENTS ON ("SAOPŠTENJA") OF THE NEW SCHOOL (OF ARCHITECTURE)
}

\section{A B S T R A C T}

The comments on "Saopštenja"(Informer - Notices) of the New school (of architecture) represent the analysis of the publication of a group of bulletins which during the period of 1970/1971 was edited by the Tripartite Committee of the Assembly of the Working Community of the Faculty of Architecture (as abbreviated The Board for the New School), with the intention of presenting to the public the process of tuition reform at the Faculty of Architecture. Being the Dean and the Chairman of the Committee at that time, Prof. Bogdan Bogdanović was the most significant participant in the reform process, and by that fact also the most responsible person for the contents of "Saopštenja". Today, these bulletins present the most valuable documents of the reform process of that time which enables one to follow both the implementation procedure and also the scientific and theoretical aspirations within the field of architecture and urbanism which provided the orientation to the reform. Also, these bulletins in a rather interesting way present the beliefs of that time on which manner the tuition within the field of architecture and urbanism should be carried out, particularly in respect to the significant social, political and cultural circumstances of that period. At the same time, this analysis attempts to find out the causes due to which the tuition of the New school of architecture lasted for quite short time.
Milorad Mladenović

University of Belgrade - Faculty of Architecture
KEY WORDS

BULLETINS "SAOPŠTENJE" THE FACULTY OF ARCHITECTURE

TUITION REFORM

THE NEW SCHOOL

INFLUENCES UPON THE REFORM

METHODOLOGY OF REFORM

BOGDAN BOGDANOVIĆ 
"Saopštenje 1970-71" is a document in the form of a group of bulletins stored in the Library of the Faculty of Architecture in Belgrade and consists of the consolidated "Saopštenja" incorporated in a unique publication without the library number (ISSN) and for the purpose of providing the readers with an insight into a set of bulletins which studied the work and progress of the reform at the Faculty of Architecture in Belgrade during 1970. and 1971. These collected bulletins have been verified by the seal of the Library of the Faculty of Architecture of the University of BELGRADE, however the collected bulletins themselves have not been filed under the Library file number which rather indicates the intention that the two-years' issues be compiled in a unique whole and be placed for the insight of primarily the readers, the employees at the Faculty, or only to be saved from obscurity, than to produce a unique bibliographical publication from the existing documents.

"Saopštenje 1970-71" consists of 14 issues of bulletins which were published as of 20 November 1970 until 8 June 1971, with an additional special issue published on 21 April 1971 and bound at the end of the collected bulletins. It is interesting to note that in the course of publishing "Saopštenja" the pagination was done which consequently represents the continuation of page marking from one publication to the next, so that the entire number of pages of "Saopštenje" amounts to 170 with 12 pages of appendices. This indicates to the fact that the intention of the authors of the bulletin publications at one moment was to convert the bulletins into a book as a referential publication, however, it has not been realized. The reason being in the most likely circumstance that the tuition reform project consequences lasted for very short period and that after the newly conceived reform of tuition ceased to be valid the publication itself was no longer topical.

The editorial to "Saopštenje" No. 13. was entirely dedicated to the aspirations of the Tripartite Committee in respect to the publication and discussed the concept of converting "Saopštenja" into a continual "scientific-theoretical periodical" or "regular publication".

Unlike the archive collection of bulletins itself, all individual bulletin copies were marked with clear bibliographical data. In the heading of each individual publication there was stated that the bulletin publisher was THE FACULTY Of ARCHITECTURE OF THE UNIVERSITY IN BELGRADE, TRIPARTITE 


\section{COMMITTEE OF THE ASSEMBLY OF THE WORKING COMMUNITY ${ }^{2}$} FOR REORGANIZATION OF THE FACULTY OF ARCHITECTURE, as abbreviated: THE BOARD FOR THE NEW SCHOOL, the date of publishing was stated, publication number and the publication title ("SAOPŠTENJE"). It was not stated in what number of copies the hectograph printing was done, however it has been presumed that each individual copy was printed in a large number of copies (most likely about 300 copies, author's comment), primarily for all the employees at the faculty, and then also for the students and other professionally interested reading public. It was already after the first published bulletin that there appeared the publisher address in the very heading (BELGRADE, 73/II BULEVAR REVOLUCIJE STREET), as well as the note: "All written comments and proposals as regards the reform of the Faculty of Architecture to be kindly sent to the above mentioned address. For all information kindly contact us at telephone number: 20747 ”. After the $10^{\text {th }}$ edition of "Saopštenja" this note has not been included any longer. As of the $12^{\text {th }}$ bulletin at the end of the publication there was a note that the publication "was duplicated in the duplication technique of the Yugoslav Civil Engineering Center, Belgrade, 84 Bul. Revolucije Street."

The last publication (No. 14) was specific by the fact that "Tripartite Committee" was omitted from the heading and that the publication was printed on the different paper color (blue). At the last page of that publication the editorial staff was presented (all future members of the Teaching Department for Visual Communications of the Faculty of Architecture, author's comment), the copy editors ass. Nikola Dudić, architect, as well as the author of layout preparation and page make-up ass. Aleksandar Radojević, architect. That last bulletin was thematically specific and concerned exclusively the issues of design, with a specific front page and along with slightly changed layout of the pages themselves.

The above mentioned special bulletin at the end of the document in the heading did not have Tripartite Committee as the publisher, it was published two weeks after the $13^{\text {th }}$ bulletin, and before the last one, the $14^{\text {th }}$, with slightly altered front page and with only one communiqué (notice), a rather characteristic text of Bogdan Bogdanović, the Dean of the Faculty at that time, which further on in this paper will be cited and commented. Also, in this special edition the full contents of all the previous "Saopštenja" was provided on several pages. Also, all former editions also included the lists of tables of contents of all previous editions. 
The characteristic contents of each of the individual bulletins, with diverse types of variations, consist of:

1. The reports from the meetings of so-called "Tripartite Committee"3

2. "Glosema" -Glosses ${ }^{4}$ incorporating diverse types of academic texts, expositions and reflections of the teachers, associates and other involved persons on the contents of the tuition at the Faculty of Architecture, and in the function of developing the new syllabus and program;

3. Various charts and various work applications which are in function of developing the new syllabus and program;

4. Various types of polls by means of which the public interests in respect to the development of so-called "New school" were established;

5. Specific (topical, author's comment) page layout and editing the very contents of the bulletin;

6. Specific vignettes and illustrations (being in the function of anticipation of the new concept of the syllabus and program within the field of architectural education, author's comment).

It is undisputable that this informal collection of bulletins represents the most integral document of the reform processes at the faculty of Architecture in Belgrade between 1970. and 1973. at which time those processes in forming the so-called New school of architecture were completely discontinued. Besides the "Saopštenja" bulletins, out of some more significant documents that concern the reform in that period, one can still make use of so-called "Školska knjiga (School book)", being the official document of the syllabus and program by means of which the coordinated reform results are implemented in the very realization of the syllabus and program, archive documents of that period being the products of the Minutes from the meetings of various forums such as Educational-scientific councils of the faculty, meetings of the Working Community, meetings of the basic Organization of the League of Communists at the Faculty, etc., a number of documents produced by the participants involved in the reform process and which were produced by those participants as agreed upon and coordinated documents or their own suggestions or opinions on the reform process, etc. Also, it is certain that the significant and extensive public polemics held in respect to the reform at the Faculty of Architecture is interesting, and which was published in one issue of the daily newspapers of that time, in weekly newspapers and professional journals, ${ }^{5}$ as well as a 
rather significant publication entitled "University Tuition of Architecture in Serbia 1846-1971.", by the group of authors with an annotation" Unpublished manuscript" published by the Faculty of Architecture of the University of Belgrade in 1996 ., which represents the integrated working material on the history of the Faculty of Architecture, created at the time of reform itself, and published about two-and-half decades thereafter, without editing the original texts. Also, the personal documentation of the stakeholders would have been rather significant for the topic of this text, however, this documentation had not been archived and made available to the public or was presented in such way that, for the time being, it is not available to the researchers. Not much has been written on "The New school" and there are no publications out of which something more can be learnt about this period of history of the Faculty of Architecture in Belgrade than from the sources themselves in "Saopštenja". Certain annotations on "The New school" were provided by the author of this text in his part of the monograph which mostly dealt with the reform processes as per decades within the field of education in Visual arts at the Faculty of Architecture in Belgrade and covered the period following the WW2 until the end of the last century, and by that fact that the annotations were provided on the subject period as well. ${ }^{6}$

The fact that the collection of bulletins "Saopštenje 1970-71" represents the most integral review of "The New school" does not ensue as much from systematization of the collection itself and its scientific or theoretical validity within the framework of the whole of the published bulletins, as much from the circumstances that this informal collection of bulletins represents one large group of the topical notices, declarations, statements, lectures ('glosemaglosses"), analyses, applications and other documents of that time which help to conjure up in a most convincing way for the present-day reader the entire atmosphere of creation and realization of "The New school", its open and hidden intentions, its aspirations, its specific language which opens and conceals the meanings and that which is rather important for the present-day reader, provides a very good survey of the concepts and opinions the likes of which are formed at a specific historical moment not only at the Faculty of Architecture in Belgrade, but also in the society of that time and its culture as a whole. Also, this document speaks about the specific cultural synergy the likes of which was established in the country of that time and at the certain moment, first of all and specifically in Belgrade, as well as on all divergent political, social and cultural effects of the period. 


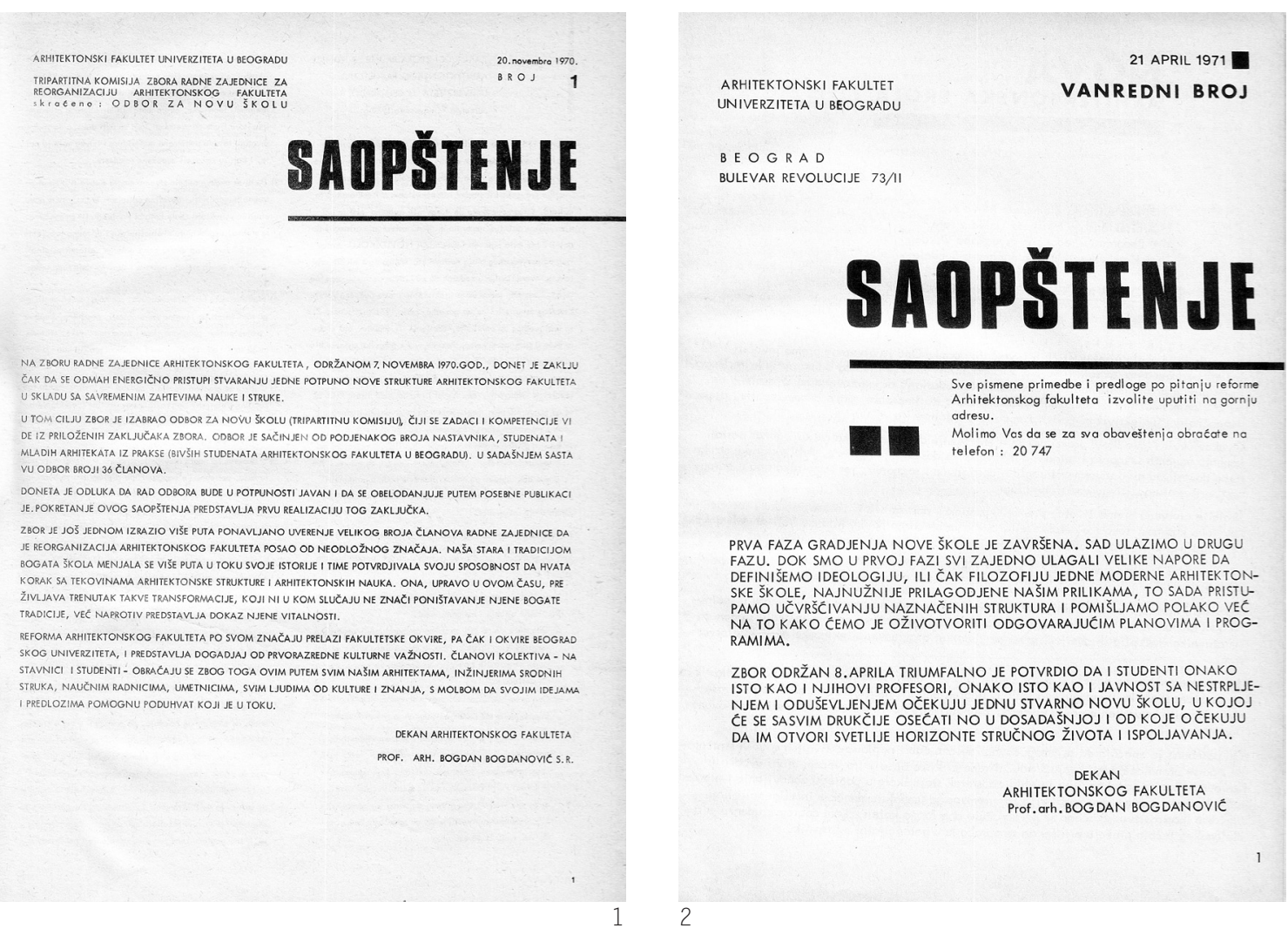

Figure 1

Front page of the first issue of ,Saopštenje“

Figure 2

Front page of the special issue of „Saopštenje“ at the end of the collection 
From the standpoint of today's theoretical periodizations one may take the liberty and state that in this document the anticipation of the future opinions on the tuition of architecture, on the architecture itself is demonstrated, but also on the future culture, as far as the political and social presumptions the likes of which will soon be actualized anew in the future of one society, perceived from the present prospective.

Also, a careful study will lead as well to the cognition on all aggravating circumstances for development of the concept on culture in a specific, and in the extreme, totalitarian society in which communication among the diverse stakeholders at all public levels would be meaningful with politicization, avantgarde and retrograde opinions and actions, and even with the circumstances that the stakeholders essentially were not in position to control and freely direct all their actions. These ideological turbulences, at the utmost, gave rise to the circumstances that the reform process at the Faculty of Architecture in the period between 1970. and 1973., was discontinued, even though it cannot be denied that it left behind certain changes, even at least within the field of tuition at the Faculty of Architecture in Belgrade, having at its own time significantly greater ambitions.

\section{THE CIRCUMSTANCES OF REALIZATION OF THE REFORM PROCESS AT THE FACULTY OF ARCHITECTURE IN THE LIGHT OF THE PUBLICATION "SAOPŠTENJA " OF THE NEW SCHOOL}

The initiation for setting the reform process of the education at the Faculty of Architecture in Belgrade into motion, which soon thereafter would be marked under the notion "The New school" (of architecture, author's comment), was conditioned by a whole series of comprehensive social and local factors which in mutual constellation resulted in that process. In that respect I primarily mean the following circumstances:

1. comprehensive social climate following the year 1968.,

2. changes which occurred in the political, economic and cultural structure of the society at the beginning of the seventies;

3. definite and institutional opening towards the western economic and cultural model,

4. substantial improvement of overall economic and social climate in the society; 
5. a pronounced discontent in respect to the principles and conditions of the present system of education, specifically in the conditions of education within the field of architecture (exactly for that reason since clear divergence of the local and wider topical scientific-theoretical models is perceived, particularly the West European-Atlantic model);

6. a significant change of the cultural paradigm at the beginning of the seventies, both globally, and also in the country of that time;

7. the emergence of the new cultural, social and political elite in the Serbian society.

It is just for the reason of such powerful initial factors that it is not possible to perceive the emergence of "the New school" as socially and culturally separate manifestation. It happened in the synergy with numerous manifestations characterizing Serbian society at the beginning of the seventies. Here I mean a whole series of manifestations in a wider social spectrum, from significant political events both in respect to the beginning and later on with the progress of the political campaign regarding constitutional amendments in the SFRY which would be finalized by adoption of the new Constitution of the SFRY in 1974, and also in respect to the emergence of so-called Serbian liberalism , to the cultural movements such as "Mediale", the Belgrade and the Novi Sad conceptualism, and even wider however not less important manifestations such as the emergence of "Crni talas (Dark wave)" in the Serbian movies, etc. All these factors have a rather pronounced effect upon formation of the reform movement at the Faculty of Architecture in Belgrade and this thesis may easily be recognized also in the full concept of "Saopštenja" bulletins.

Starting from the last above mentioned factor (7.), as a pronounced manifestation of completely new cultural and political model in the Serbian society is the spiritus movens of "The New school", the architect, the artist and the urbanist, Prof. Bogdan Bogdanović (1922-2010), at that time the corresponding member of "SANU" (Serbian Academy of Science and Arts, abbr. SASA) and the Dean of the Faculty of Architecture in Belgrade. Besides his ample biography and bibliography that accompanies him and which will not be specially accentuated in this work, several important circumstances that place Bogdan Bogdanović at the said position should be highlighted: 1.his function as the Dean of the Faculty of Architecture ${ }^{7} ; 2$. his specific scientific, artistic, academic and political career; 3 . his specific psychological and 
character profile being one of the essential influential factors which installed him at the position from which he commenced the reform of the tuition of architecture. ${ }^{9}$

These Bogdanović's characteristics, which at an interval may seem as fundamental condition of his reform endeavors, do not have a valid point as the only reasons of initiating the reform process at the Faculty of Architecture, however these reasons certainly made it possible for Bogdanović to take over the role of the School leader with his ideas on the tuition of architecture. At this point I primarily mean the events which preceded his appointment and which relate to directly passed reform plans of the former management which that management, headed by arch. Stanko Mandić, characterized as "revolutionary". Discontent with this new concept of tuition resulted in polemics in public (and even in student protests, author's comment), in which through a number of texts ${ }^{10}$, the reform documents passed were refuted in full and their radical amendment requested. It should be emphasized that particularly in Bogdanović's text "The Architectural Chalk Drawn Circle" fully, gradually and as per items, all important parameters for rejecting reform plans passed under the management of the Dean Stanko Mandić were explained, but also the parameters for commencing the process of the entirely new reform, in which Bogdanović, as the "only academician among professors" would play a crucial role ${ }^{11}$.

The entire conceptual and ideological range of "Saopštenja" as a representation of the newly commenced reform process of the New school can be found between two Bogdanović's editorials, at the front page of the first issue and in the editorial of the Special issue dated 21 April 1971, at the very end of the collection of bulletins "Saopštenja". Besides already mentioned description of regulation of the structure for realization of the New school the very point of commencement and necessity of its realizations were discussed:

“...The Assembly (of the Working Community, author's comment) expressed once more the many times repeated belief of the majority of the members of the Working Community that reorganization of the Faculty of Architecture was the affair of imperative significance. Our old and rich in tradition school has changed several times during its history and thus affirmed its ability to catch up with the achievements of architectural structure and architectural sciences. Right at this moment it is experiencing such transformations, which in no case 
means setting aside its rich tradition, but on the contrary, presents the proof of its vitality.

As per its significance, the reform of the Faculty of Architecture goes beyond the faculty frameworks, and even the frameworks of the University of Belgrade, and represents an event of prime cultural importance. The members of the personnel - the teachers and the students - address for that reason and this way all our architects, engineers of related trades, scientific workers, artists, all persons of culture and knowledge, with a request to help the ongoing endeavor with their concepts and suggestions."

The editorial of the Special issue at the front page reads fully as follows: "The first phase of development of the New school has been completed. We now enter the second phase. Whereas in the first phase we have all mutually made great efforts in defining the ideology, or even the philosophy of one modern architectural school, adjusted to our circumstances in the most basic way, thus now we proceed with strengthening the stated structures and already slowly contemplate how to actualize it with corresponding syllabuses and programs.

The Assembly held on 8 April established with a triumph that both the students same as their professors as well, same as also the public impatiently and with enthusiasm awaited a really new school, in which they would feel completely different than in the present one and which they expected from to open up brighter views of scientific life and manifestation."

From these two brief manifest texts one can immediately see the obvious intention that the reform project be placed at the plane which "goes beyond the frameworks of the Faculty of Architecture in Belgrade" and that "it was of the prime cultural importance". The reasons for such expressed demonstrativeness (manifest aspect) of the reform process lie in numerous internal and external factors and circumstances. It primarily means here:

1. the political and social climate created following the events in 1968.;

2. the emergence of so-called Serbian liberalism on the political scene of Serbia at the beginning of the seventies;

3. activation of the procedure of amendment of the Constitution of 1963.;

4. changed cultural climate in the Serbian society and its liberalization in that period. 
5. the new social and scientific circumstances in the world at the beginning of the seventies.

All these significant socio-political shifts resulted also in a favorable climate for commencement of the reform procedure. These intentions will be read from "Saopstenja" first of all indirectly, however, it is more than clear that all program positions start from the issue of social conditionings of architectural trade and the requirement that the reform program is the first-league representation of the growing liberalism, and even also the leader of such a process, certainly in the general educational system of that time, but also in the system as a whole.

1 / Even though in the circumstances of that time the events of 1968 were fully absorbed and incorporated within the legal courses of the political system the fact cannot be avoided that the vigorousness of these events, the small real benefits for the very students' movement were brought down to the plane of softened Broz's rhetoric and the general belief that it was necessary to enter into somehow more liberal social relations, the fact is undisputable that at the University there prevailed the climate which still counted on the energy of the protest which took place two years before. The text of "the Conclusion of the Assembly of the Working community of the Faculty of Architecture of the University in Belgrade held on 7 November 1970" which the first "Saopštenje" bulletin opens with, after the mentioned editorial, starts exactly with the words which base the commencement of the reform procedure on the initial events of $1968^{12}$. This undoubtedly confirms the primary initiation in starting the reform process. To that effect, the Assembly provided a list of conclusions at the end of the text ("In order to facilitate the work of the Board..." and which will "...serve as basic principles...") for ex: 1. "New school in respect to the old one has to be the school of completely different, higher ethical and scientific standards", 2." School has to be open to life...", 3. “... it is necessary to conceive and fully define a completely new school structure which as per definition would enable continuous, incessant evolution ...", 4.-7. it is insisted on so-called "Differentiated tuition" and other new organizational forms, 8. it is pleaded for the new profiles of teachers and insisted on participation of visiting teachers, 9.-10. it is requested ".... a fair selection of the most talented younger professionals...., as well as the change of the way of student admission, and under 11. in the most characteristic way it is highlighted: "The new school lifts the hierarchical relationships between the students and the teachers and unites them into a unique working body. The principle of self-management has to 
be implemented in full...", as far as the invitations that the students and the teachers jointly participate in articulation of the program and on mutual and common to both evaluation of work.

All above mentioned principles fully correspond to the students' requests and simultaneously affirm a full socialist and self-management model of education as was presented also in the requests of 1968. One Bogdanović's interview of a later date confirms these political positions of the New school, calling it "Red". ${ }^{13}$

2 / To what extent was the doubt in respect to the support of the liberals from the interview in footnote no. 11 true, is not easy to assess, however Bogdanović's statement is certainly indicative. It is also difficult to assume that in that relationship there were any significant discords in respect to the concept of reforms at the Faculty of Architecture. This statement ensues from several facts ${ }^{14}$ which indicate that in those circumstances there existed significant coordination of political factors in the country at that time. This is confirmed primarily by the documents of the basic organization of the League of Communists of the Faculty of Architecture which fully provide support to or orientate the fundamental conclusions of the Assembly of the working community of the FA and provide basic recommendation which correspond to the principles of the reform and organization of the future new school, in the advanced stadium of establishing the reform course ${ }^{15}$. Through the concepts of "Saopštenja" and glosses as the contents of the publication, the intention towards a specific model of reform is more than identifiable and in which reform the so-called techno-managerial components of education are stated, and naturally, in line with the existing socialist social order of the contemporary SFRY and without clear public criticism. It is noticeablee that in "Saopštenja" themselves there is no conventional party rhetoric and that it places them at the plane of quite specific documents which differ from the usual contents of that time which accompany the political and reform processes within all social fields. ${ }^{16}$ It is only one text of the Committee for work and working relations of the Faculty of Architecture under the title : "Fundamental principles on Self-Management Bodies at the Faculty of Architecture" that dealt with the political and procedural self-management relations at the Faculty ${ }^{17}$. The socalled techno-managerial concept, which lather on was one of the main reasons for criticism of so-called "liberal stream" within CCLCS (Central Committee of the League of Communists of Serbia), can be recognized also in the absence 
of this political rhetoric in implementation of the reform at the Faculty of Architecture (which is excessively "liberally" understood self-management political rhetoric, author's comment).

Through various contents of "Saopštenja" it can be noticed: 1. obvious need for distribution of general scientific-theoretical knowledge, primarily those which come from the western (capitalist, author's note) science, as well as also the relevant scientific knowledge dealing with the contemporary and then topical projections of the future and which orientate the educational process ${ }^{18} ; 2$. significant stressing of the issue of relationship of the scientific and production relations in the educational system and insisting on establishing relevant social production needs which should orientate the ways of educations, as well as insisting upon the qualitative relations of the theoretical and practical within the educational program ${ }^{19} ; 3$. opening up the issue of rather broad so-called "diversification" or specialization by means of which clear orientation towards defined requirements of economy and culture (as practice) is established ${ }^{20} ; 4$. the new staging of the production relationships in the educational system at teacher-student relation and not only through political representation of selfmanagement but in a real production relationship in which so-called "atelier" concept of tuition is abolished and the simulacrum of future design bureaus or relevant "research teams" introduced into tuition in which the teacher represents the process manager (or "tutor", as occasionally emphasized, author's comment) and the student independently forms his results simulating the real design procedure such like already exists or will exist in the economy; 5. introduction of so-called "cubicles" being a prerequisite for the individual position for each student as a manner to fully simulate the real working conditions for the students after completion of the studies; 6.insisting on student teamwork as another one of the system of copying the real working conditions in economy.

All educational systems mentioned herein are exclusively orientated towards training for the future production process stripped of any ideologization of that process. This certainly does not abolish the broader competences and knowledge (the question of "universality" as asked by V. Mušič in the gloss No. 20), however in the reform they are directly implemented through the system of "diversification" as well as establishing the general and individual knowledge for the studies as a whole and for each student individually. 
The obvious intention that the education would be placed in the function of economy and culture (as the practice), deprived of any narrow ideological and political bases, represents the basis of one techno-managerial approach to education which, in its basic tenet is "liberal" and open-minded for the circumstances of that time (in the text that follows cultural and ideological bases of such type of projection of educational system will also be discussed).

3 / Even though the political activities in Serbia, orientated towards the amendment of the 1963 Constitution., progressed mostly on the issues of "adjustment" or amendment of the socio-political order of the Country, and which mostly were reduced to questioning the inter-republic relationships, the issues of the national strategies of the individual peoples and nationalities of the SFRY of that time, and particularly in Serbia, with the criticism of its, more expected than really proclaimed centralistic tendencies, it is undoubted that the corpus of questions and dialogues associated with the issues in education was caused equally by the events of 1968., as well as by the requirement that the education be adjusted to the unavoidable concepts to be produced by the future Constitution. Certain confusions is reflected in a rather exposed questions of the new function of education and its reform, through diverse forms and parallel with pronounced political campaign regarding the future Constitution. ${ }^{21}$ The question of self-management at the University was there posed as a key one and it made a type of indirectly anticipated intention within the reform. ${ }^{22}$

At the second, practically alternative, level of reading these circumstances it is impossible to bypass the fact that "liberalism" of the reform processes at the Faculty of Architecture represented a type of one quiet visible and parallel course established with political intentions. Winning the media "freedom" at the beginning of the seventies produced comparative considerations of the position of education in contemporary SFRY and through numerous texts in the publications of that period one could follow the social interest in respect to the conditions at the University. It is not a small number of texts and analyses that related to the comparison to the contemporary, mostly western, concepts of education, as well as analyses of the actual condition. It is doubtless that the radical concept of reform of "the New school" both formally and substantially related to the issue of liberalization of education. In respect to this tendency, it is not unusual to presume that together with the collapse of so-called "Serbian liberalism" the very reform of the New school found itself in an unfavorable position. 


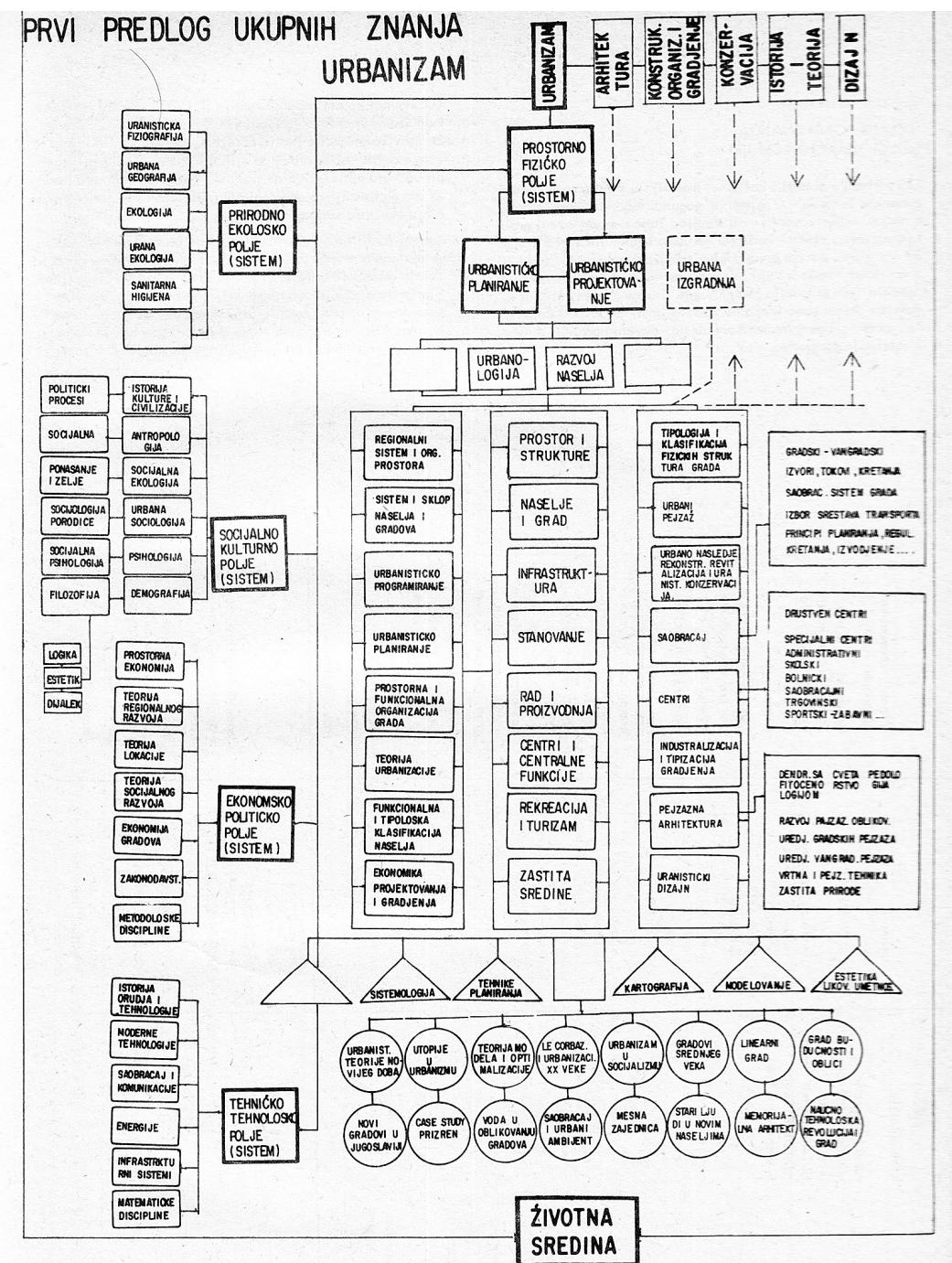

Figure 3

Chart „The Proposal of the total knowledge (for the field of) Urbanism“ 


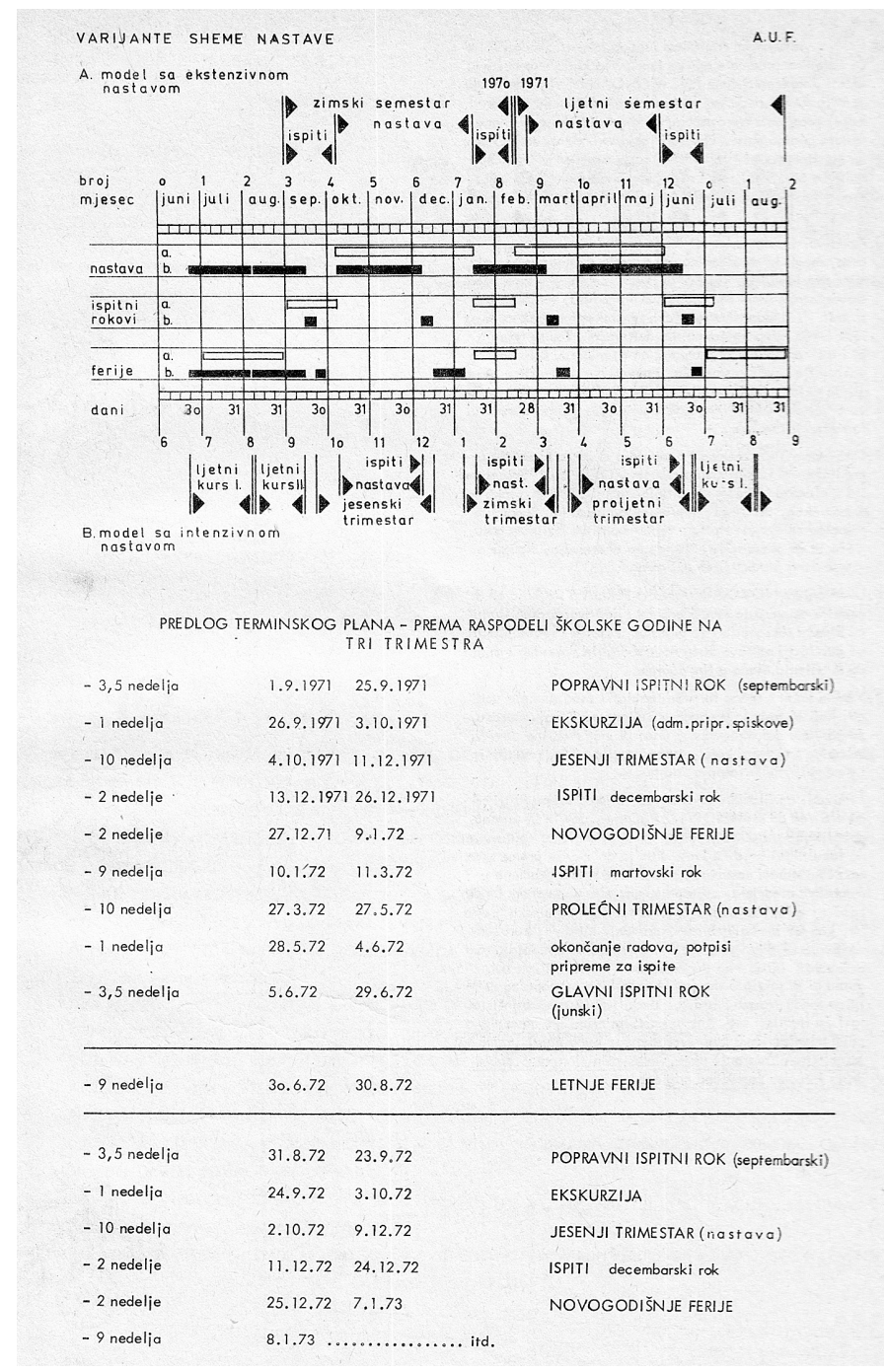

Figure 4

Chart of one of the variants of schemes of tuition and one Proposal of the Term plan - according 
In the bulletin "Saopštenje" there are no clear comparisons of the reform of tuition in architecture and dominant political circumstances in respect to Constitutional amendments, however through the entire reform strategy represented in "Saopštenje" this link can clearly be perceived.

4 / It is almost like in the case of coinciding of periodization of the reform of the New school with the emergence of so-called "Serbian liberalism" personified in the political advents of Marko Nikezić and Latinka Perović, that the events in the culture of that time could be followed and that way the doubtless parallelism of the cultural events and cultural policy with the reform of the New school could be perceived. The most indicative coincidence relates to the emergence of the so-called "Dark wave" in Yugoslav, and particularly, Serbian film of that time, The "Dark wave", as doubtless long-lasting manifestation, spreads out in theory from the crucial 1968. till 1973, when, under the strong political pressure it was almost extinguished or at least experienced the most significant public and political dogmatic pressure, when also the reform of the New school was suspended. In the analysis of Bogdan Tirnanić who dealt also with the origination of the very name of the film movement "Dark wave" there is one interesting comment in which the architect and painter Leonid Sheika was associated with the very origination of the notion "dark wave", first of all due to observations in the local criticism of that time in which the whole movement Mediale was called "the Dark wave" in painting". The links between Mediale and the Faculty of Architecture are extremely significant independent of somehow displaced periodization, however there are several rather essential facts which link these manifestations. The major inspirers of Mediale are Leonid Sheika, Siniša Vuković and Miro Glavurtic, out of whom the first two were architects as per their education, and also the architect and painter Vladimir Veličković, as well as Milić Stanković, who commenced his studies at the Faculty of Architecture, belonged to Mediale. This link will later on be written more about, however it is of significance that the generation of the artist of Mediale (born mostly between 1933 and 1935) commenced their activity in mid fifties, just at the time when Bogdan Bogdanović published a series of texts in NIN, out of which one of the more famous texts was under the headline "The Ornament and Crimes" in which Bogdanović criticized Los as a distinct modernist deprived of the feeling for ornament which Bogdanović propagated even before his artistic realizations. Such actions, which later on Bogdanović subsumed under "the sins of youth" were equally radical for their times as a whole conception and aesthetics of Mediale. It would be significant to study this link in more detail. 
However, the pursuits which in that period emerged within the field of socalled "conceptual art" and which with its development in us also commenced some time after 1968., are somehow closer to the character of the concept of the New school. This practice, which in Belgrade was most clearly personified in the group of "The Six artists" who were active in the Students' Cultural Centre $^{23}$ and some earlier also through the series of the Novi Sad artistic manifestations, did not experience the destiny of the "Dark wave" in the film industry and continued with its powerful activities even after 1973., and that, naturally, being under the continuous cultural, public and political lack of understanding. The link can primarily be perceived at the level of the specific relationship towards the scientific and philosophical axiomatic and analytics of the conceptualism movement such like characterized also the artistic ideology of the New school ${ }^{24}$.

Bogdanović, doubtless, will seek his ideals in that period in the works of the Land art (being the movement the rise of prominence of which dated exactly at the end of the sixties and at the beginning of the seventies, author's comment), same as it could be said for his art that it undoubtedly found its ideals in the authors such as Brancusi ${ }^{25}$.

5 / The general social climate following 1968, and particularly at the beginning of the seventies was determined by the ideology of the scientific-technical progressivism gaining ground which was based on the overall stabilization of primarily production and economic and financial circumstances following the WW2. Whereas this ideology calmed down with the post-war disappointment, in the seventies it experienced a new momentum ${ }^{26}$. Although the most significant scientific-technological inventions dated in the first decades of the $20^{\text {th }}$ century, the development of cybernetics started with the researches of Norbert Wiener at the beginning of the forties, and cosmonautics started with its programs of space conquest with the flight of Yuri Gagarin in 1961, it is rather significant that the $20^{\text {th }}$ century presents an incredible impetus of scientific-research work, such as has not been recorded in history ${ }^{27}$. Besides the significant discoveries in the seventies, like the technique of DNA recombination, or the beginning of the development of "the theory of chaos" for example, the discoveries that the exceptional impetus of technical-technological, commercial and economic development of the mankind started seriously to endanger the very environment is of particular significance for the subject analysis. 
Ecology as science started to develop exactly in the period at the beginning of the seventies of the $20^{\text {th }}$ century and that knowledge will substantially affect the fact that the researches of the notion of environment are placed as fundamental in the concept of the reform of education at the Faculty of Architecture in Belgrade and first of all through the awareness of "the integral environment" being the totality within which architecture acts both as the science and the practice.

All above mentioned conditions and effects upon the concept and character of the New school are neither the only ones of significance, however certainly nor the most significant ones within the context of deliberation in this text. It would have been interesting to study the entire spectrum of conditions, from so-called "new age" ideologies and cultural and sub-cultural movements which color the character of Bogdanović's reform to then topical events within the field of architecture and urbanism, mostly on the trail of the unique social, philosophical and theoretical processes and in continuously proclaimed synthesis of influences, but for the text itself these comments are sufficient from the viewpoint of the fundamental concept of the author of the text.

\section{"SAOPŠTENJE" BEING THE REPRESENTATION OF THE REFORM PROCESS AND THE EFFECT OF THE PUBLICATION UPON THE VERY REALIZATION OF THE REFORM PROCESS}

The reform procedure at the Faculty of Architecture in Belgrade can be studied from the reports from the meetings of the Board for the New school published in the bulletins "Saopštenje".

Following the mentioned editorial of Bogdan Bogdanović by the report from the meeting dated 9 December 1979. ("Saopštenje" No. 2, p.5), about two week later, the principle charts of organization of the School were presented and it was stated how "the New school could be realized only by clear definition of the school goal" and " "by precise definition of the organization of work...in the full function of the proclaimed principle, the element of public." Two "priority" questions for the further work were precisely stated in the report: "- How big is and what is the ideal pool of knowledge from the field of architecture and urbanism on which our trade depends on?" and "Which professional profiles of architects in practice can be stated nowadays?" 
In the Report it was stated that these two questions should be forwarded by the Management to the Teaching departments in order to enable the Teaching departments to formulate the answers.

In the report from the third meeting ("Saopštenje" No. 3, p. 9) within the context of the answers to the above mentioned questions there was a poll organized ("questionnaires") out of which one relates to the questionnaire For Polling the Companies and the other one to the questionnaire For Polling the Architects ${ }^{28}$ And the fourth meeting proceeded in the attempt to determine "compulsory" and "non compulsory" knowledge of the students of architecture and with the proclaimed goal of determining the answers to the questions made and awaiting the reaction of the departments, in order to elaborate in "Saopštenje" No. 6 dated 20. December, 1970., the department answers prepared through individual narrations and discussions and to publish in the same issue the total diagram of answers to the Faculty department and textual explanations accompanying them. This rather voluminous material (which was certainly expected, author's comment $)^{29}$ had an effect that at the sixth meeting from the report in "Saopštenje" No. 17, p. 41), "breaking down...of the entire image: was ordered and establishing of "The Catalogue of knowledge" proposed, being essential to implement the enormous quantity of matter through the tuition syllabus and that the ultimate goal of this "breaking down" be "defining and graphical presentation of the total and common scheme of the pool of knowledge for the school as a whole."

Further in the reports from the meetings of the Board one could follow two parallel courses of work: one relates to the issue of visiting teachers and the other one to further definition of "the ideal pool of knowledge:" and preparation of "organizational/tuition schemes of the New school" against the statement that "the New school would seek the fundamental forms of its future structure in one of the numerous possibilities of diversification", however, it would not be implemented "ad hoc", but in parallel or gradually.

Since until 3 February, 1971., the variants of "the first organizational-tuition schemes of the New school" were prepared it was proceeded with their consideration, and the following proposals particularly stood out: a) the proposal on successive increase of participation of the visiting teachers... (under the working title opening of windows); b)c) two proposals of the 
mechanisms of diversification (under the working title branching tree and the pyramid); d) introduction of various "forms of sociability" from the first year till completion of studies (under the working title of heteria ${ }^{30}$ ); e( studying the introduction of the expressive orientation ("no title") (“Saopštenje” No. 10, p. 69).

At the $11^{\text {th }}$ meeting of the Board "the possibilities of better and more fair allotment of the space in the Faculty building" was studied and it was stated that such allotment will be in favor of the teachers in relation to the students. Also, there came to the proposal that "experimental groups" be formed in which "by means of simulation the behavior" of the students would be tested in the situations of choosing the tutor, determining the elective course, approach to the work with the visiting professors, etc., and that being "in the presence of the faculty and outside the faculty public".

Besides, in the same "Saopštenje" No.11 the conclusion from the $12^{\text {th }}$ meeting of the Board was published in which "the refined strategies of the future school" were stated: trimester calendar and 28 days of work weekly, much diversified tuition, mass invitation of the visiting teachers, work in groups, selection of the tutor ("who may work for only one year with one group") ${ }^{31}$ At the $13^{\text {th }}$ meeting (page 84) there came to the proposal of a group of the visiting teachers, and at the $14^{\text {th }}(\mathrm{p} .84)$ the proposal of the department for design was discussed on "the councils of the years (which within the possibilities of free disposal of the programs), along with the parity relationship of the teacher and the students (would become) the basic tuition-self-management units of the faculty".

In "Saopstenje" No. 12 dated 22 March 1971, the reports from the $15^{\text {th }}, 16^{\text {th }}$ and $17^{\text {th }}$ meeting of the Board were presented, from which meetings the participation of the young architects can be singled out which Club prepared for the $16^{\text {th }}$ meeting "a rather well developed diagram of the basic organizationaltuition chart", and in the report it was stated how the plan "was received with much approval" and that "the number of participants at this meeting exceeded one hundred." At the $17^{\text {th }}$ meeting the issue of self-management was discussed "since at the recent meeting of the council of the Faculty of Architecture favorable opinion of the teachers was provided on the request of the FBUS (Faculty Board of the Union of Students) of the Faculty of Architecture for the parity of the students and the teachers in all faculty bodies". 



Figure 5

Vignette with description (it.) „Fig.12 - Nella $<$ macchina a sei ruote $>$ qui riprodotta si ritrovano gli schemi dimostrativi delle diverse Cabale“ (Fig.12 - „In <the six wheels car > which are herein presented there are illustrated schemes of different Kabbalah“, translation J.Tolić)

Figure 6

Example of vignette combining (illustration 05) in one of the publications of "Saopštenje"“, page detail

Figure 7

Examples pf graphic contributions in "Saopštenje": 1. Below: Rhythmic surface created by superimposition of equidistant concentric circles and parallel lines. Herman Baravalle, Pictorial Mathematics; 2. At right: Moiré effect produced by the kinetic optical combination of two superimposed patterns of parallel lines and concretic circles. Gerald Oster. Conic Section II, 1964. Courtesy Howard Wise Gallery, New York.

Figure 8

Illustration by Vladimir Veličković in „Saopštenje“ No.11, the numerous works of whom accompany the text by George Melville „Grupni rad u arhitektonsko-urbanističkom obrazovanju“ (Group work in architectural-urbanist education) 
With this last meeting the report of which was published in the bulletin "Saopštenje", the organizational process of the reform at the faculty of Architecture in the course of 1970 and 1971 was presented in full. Later on significant conclusion promoted in the special issue of "Saopstenje" and other documents will be presented, however at this point it could be affirmed that the work of the Tripartite Committee was rather active, creative and without any special disagreements in arriving to the conclusions. Naturally, these reports primarily concern the fundamental principles on which the New school would be based, and only from the so-called glosses the educational, scientific and cultural components determining the substantial range of the reform could be determined more clearly. Although at the meetings of the Board the charts of the future organization of the School were discussed, they were not individually precisely presented in the reports and the conclusion may be drawn that the educational and cultural-ideological scope of opinion which includes the reform process significantly surpasses the abilities of presentation through the defined program, and is the web of broad (actual at that time, author's comment) philosophical deliberations of the totality and functions of education within the field of architecture and urbanism.

First of all, it should be stated how in compliance with then prominent modern and progressionist comprehension of the position of science in society, the reform orientation progressed in almost manifested involution of the new scientific component of education ${ }^{32}$. The request for strict implementation of the syllabus was doubtless the trigger of the reform. Naturally, this scientific quality was opposed to the present "pseudo-scientific" quality of the old school and this heretofore "pseudo-scientific" quality was one of the substantial reasons to initiate the reform. Prevailing over the "pseudo-scientific" progressed in the circumstances of correspondence with the international scientific sources, and in line with significant cultural and political opening of the Country towards the West, not only following the breakaway from Stalin and Cominform and following reform tendencies of 1965., but particularly following 1968. when the question of cultural and educational change was made as an imperative and not only due to the very circumstances of the socio-political democratization but also due to the necessity to amortize and accumulate the discontent with the system manifested during the June 1968 protests.

This appeal for actual scientific-theoretical system in education possesses also the characteristic components related to the reform concept. Here, first of all, I 

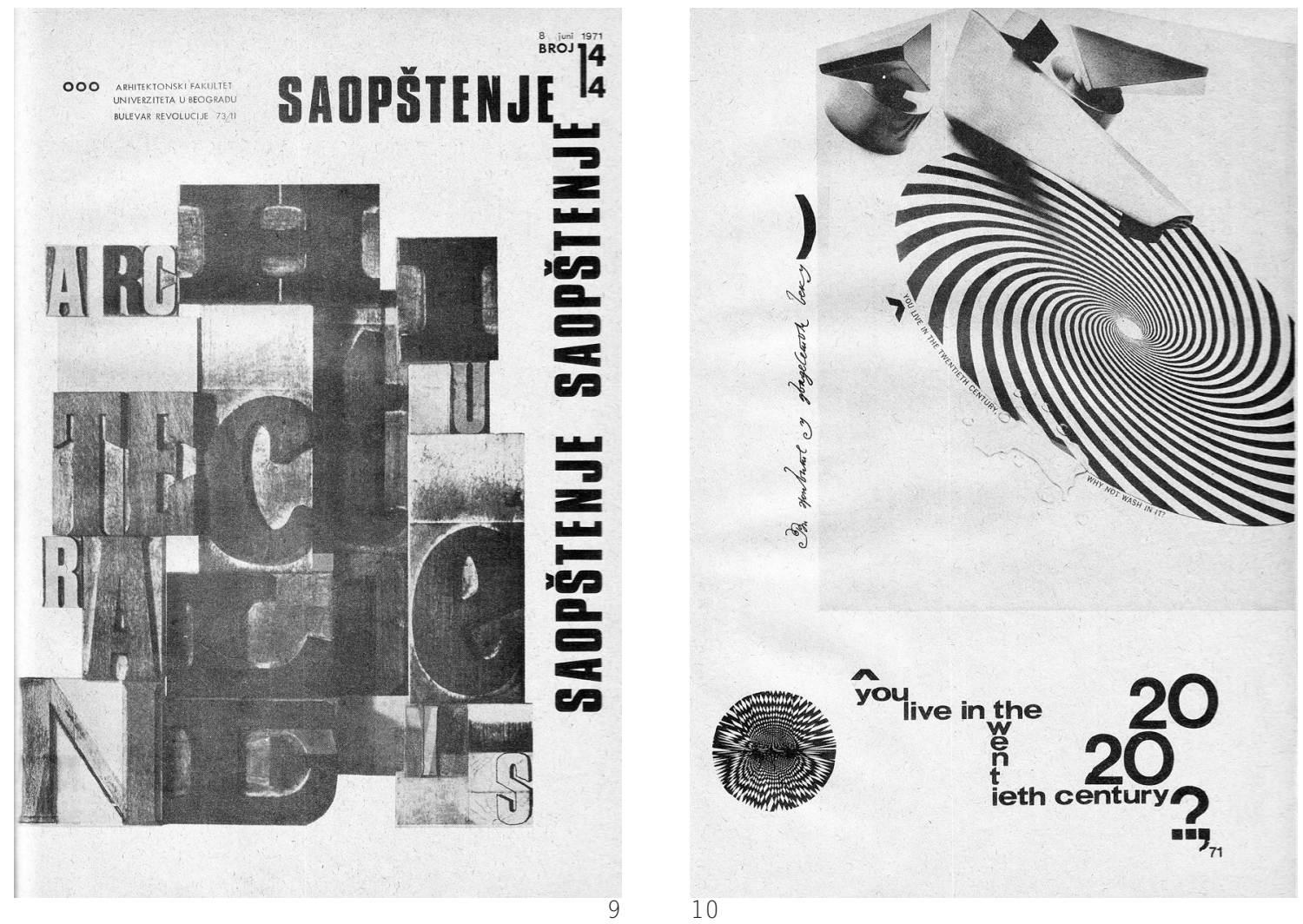

Figure 9

Front page of „, Saopštenje“ No.14 
mean the insistence on the scientific specialization in line with the spirit of the time (being the condition to experience the question of "diversification" as one of the crucial issues of reform), as well as with the insistence on progressionist component of then topical science which was entirely orientated towards the future and inclined to glorification of those disciplines which were in their infancy and which will yet in the projections of the stakeholders be seen as significant teaching fields.

From the reform orientations thus laid down certain specific (at that time new, author's citation) approaches to diverse scientific disciplines ${ }^{33}$ can be isolated. Prof. Djordje Petrović spoke about the new relations between mathematics and design through the notions of "combinations" or "theory of groups", for example., in his gloss No. 18 (p.48., "Saopštenje") he presented the survey of then topical Anderson's theory of modular approach. Social requirements within the field of architecture and building required approaching the studies of “. . . the systems of large series and sets (as) a programmed and highly mechanized chain production. Thereby designing should develop into the study of organization of the series of sets, the grid of the mathematical structure, and nominal coordination into nominal systems" for which "as an inevitability, mathematical logics, the use of electronic computers and application of the latest attainments of the scientific achievements of a wide range of contiguous disciplines (philosophy, sociology, psychology, hygiene and a whole series of engineering disciplines) $)^{34}$ "was imposed". "The standard, series and module" are postulated as a methodological inescapability in the issues of the study of visual art as well ${ }^{35}$.

Insisting on scientifically based methodology of education was also presented by Prof. Milan Djokić who emphasizing that "the tuition of the architectural design... is a programmed process" considered the intention towards :scientific" methodology of school design, which also Milan Zloković advocated for in the text "Theory of Proportions" asking, among other things "is it possible that it is permitted for the designer to follow the lead of only imagination and routine, not finding, thereby, that it was necessary to apply more concise methods..." ${ }^{36}$.

Within the request for the new science and the new methodology in the education of an architect the diverse forms of practical methodology in work with the students were also studied. In gloss 108 (p. 140. of “Saopštenje') Vladimir 
Bjelikov proposed: "the simulation model of the round table in the tuition of urbanism" with a note that this model had been known from the literature and "was modified according to the Yugoslav practice". George Milville provided the most elaborate text in the bulletins "Saopštenje" under the name "Group work in architectural-urbanist education" ${ }^{37}$ in which, following first of all the German laws within the field of education, he presented a broad analysis of conditions for group work within the field of architecture and urbanism from the most versatile aspects, from professional to the psychological ones.

If there is something that represents a complete paradoxality within the publications of "Saopštenje" then, certainly, it is a complete absence of any references in respect to then topical examples from the field of architecture even though from the very concept of "Saopštenje" and authors' concepts of glosses it is more than clear that the participants involved were familiar with the actual practical experiences of all subject fields of architecture and urbanism. The reason for that most probably should be sought in the intention of the reform protagonists not to engage in deliberation of then rather versatile (and never in the history more versatile) architectural-urbanist stage making a wide range of concepts from avant-garde, metabolism, parameter or analytical architecture, high modernism (international style) as far as the practices such as situationalism, pop-art or the first mentions of the critical regionalism. As if the reform protagonists were trying to perceive the entire reform process in a sublime way and at the level of the universal public and cultural conscience of the age being the essential condition for condensation of practical forms of architecture and urbanism. Such position can only be justified by previously stated, and is also shown by the attempt that the New school would not be ideologized at some special level in the circumstances when the global practice presented an unbelievable ideological, philosophical and theoretical versatility. To what extent this has been affected by evasion of the numerous important members of the Department for design from the direct influence upon the reform of the New school can be a rather interesting question. However, more significant interest for the general issues of economics, sociology or politics in the science of urbanism or spatial planning must not be neglected.

The entire art layout, design graphics and illustrations accompanying the bulletin are rather interesting from the specific point of consideration in the "Saopštenje" glosses. Through consequent representation of graphs which, in almost working form, follow the procedure of consulting on the reform process, 
in an attempt to sum up all the activities and intentions of the future school, it is almost as if the possibilities of clear layout or readability were exceeded. This is the logical consequence of the teaching department organized school and a large scope of knowledge which are individually argued for. Also, from the very reports from the meetings of Tripartite Committee the "consternation" is obvious and relates to the manner in which these voluminous contents represented by graphs would be formed in a unique entity ${ }^{38}$ (as the ultimate result of these graphs the School book ${ }^{39}$ was only produced as the final plan and program of the reform, author's comment) . Certain graphs describe the very reform process. This "graphic" elaboration of the process has a certain tendency to introduce clear and easy to survey scientific-methodological frameworks of the concepts set forth in the discussions on reform, and with the intention that exactly this type of elaboration (and even also the anesthetization, author's comment) of the process coincide with the scientific (analytical, author's comment) ambitions of that time in the reform. ${ }^{40}$

Starting from "Saopštenje" No. 3, after the gloss of Djordje Petrović there commenced a series of illustrations or vignettes the topic of which was so-called optical art (op-art), as the conscientiously input "cybernetics" or mathematical art, in line with the above derived comments, and which is especially promoted through the work of so-called "group for design" in the above mentioned specifically processed "Saopštenje" No. 14. The art contributions of Vladimir Veličković in the bulletin No. 11 are a sort of a counterpoint to this op-art esthetics and follow the complete mentioned ample narrative of George Milville with the obvious influence of Dado Djurić's painting art, however also against the identifiable iconographic elements which later on would be elaborated in Veličković's painting art. Certain architectonic (post-constructivism) elements are compositionally bound with the mass of anthropomorphic forms in order to build the relationship of such forms and space presented in the painting. Veličković was then 35 years old and since 1966 has lived in Paris. He was the member of the Mediale group the influence of which upon the New School has been mentioned.

The most interesting visual art aspect of "Saopštenje" was certainly represented by remarkable vignettes, which in various forms, links and density, by composing and rotation, as well as grid-type combination run through all "Saopštenje" bulletins. It is obvious that their inspirer or at lest the man influencing their layout was Bogdan Bogdanović. Vignettes show or 
thematically present the mystic Kabbalah graphic art marked by the following description: Fig. 12 - Nella <macchina a sei ruote> qui riprodotta si ritrovano gli schemi dimostrativi delle diverse Cabale ${ }^{41}$. In all subsequent bulletins this vignette was reproduced, its parts copied and lined in a regular order or created clustered structures of the same unique graphic form or part of the form. The number of these vignettes is that big that in entirety provides not only the artistic, but also a significant conceptual character of the bulletin. On the trail of this obviously important element more complex (and that much more strange, author's comment) spiritual elements of the concept of the New school can be read. ${ }^{42}$

From all previously mentioned parameters which are revealed by «Saopštenje » it is more than clear that the conceptual framework of the reform runs between the divergent premise of analytical-conceptual scientific and esthetic starting points as far as the powerful influence of Bogdanović's mysticism and spirituality which aspired towards a type of the total image of the world as the framework for education in architecture. Consequently the vastness of the requests which the reformers addressed the public with is almost infinite and often unfathomable. Along with this, all those topical new age tendencies of that time should be emphasized which the world was entirely enclosed with since 1968 and which describe not only the state of mind of the youth of that time but also a significant culturological and social move of the entire mankind ${ }^{43}$.

From the whole of narrations in "Saopštenje" the conclusion may be drawn how the issue of "the environment", which was incessantly insisted on, was at the same time crucial for understanding the relation to the issue of tuition within the field architecture like the relation to the issue of the entirety of knowledge within the awareness of the philosophical, esthetic and ethical totality.

At this place it is considered advisable to state essential circumstances which through insistence on the notion of "integral environment" in "Saopštenja" (or the environment, being the English term which the authors of glosses termed this notion) determine the substantial intra-faculty relationships, and even misunderstandings, which, eventually would ensue until the termination of the methodology of reform under the patronage of Bogdan Bogdanović. 
Namely, it is certain that the interest for this aspect of the New school resulted as much from Bogdanović's scientific-theoretical surveys as much also from the situation that Bogdanović represented not only the Dean of the Faculty of Architecture in Belgrade but (at that time) the most recent representative of the Chair of urbanism. From the first submitted "The First Proposal of the Total Knowledge (for the field of) Urbanism" within the request to the teaching departments for establishing the chart of "the ideal pool of knowledge", it is perceivable that the Chair of urbanism framed the entire framework of its tuition interests with the term of "Environment", providing the proposal that other teaching departments should also be incorporated in the identical structure (see chart on page 27., publication no. 6 of "Saopštenje"). It is noticeable that other teaching departments did not follow this model of the chart. It could be presumed that besides the proposal of the Club of the young architects (and most likely the majority of students, author's comment) other teaching departments had significant reservations (or at least the differences in their position, author's comment) in respect to this strategy, and particularly the Department of designing, which in "Saopštenje" No. 6 was represented by the text and chart by Branislav Milenković "The Ideal pool of Knowledge (the question of the Tripartite Committee)" at p. 8 of the same "Saopštenje" by means of which Milenković provided (most probably his personal, and not the departmental, author's comment) suggestions on "combined action of the present Teaching Departments... and thus each one of them in the condensed approaches would study the forms of the environment..." . At the utmost, from "Saopštenja" it cannot be perceived that the Department for designing provided any more significantly developed scheme of "the ideal pool of knowledge", independent from the great number of texts in "Saopštenje" which dealt with the methodology of architectural design, some of which have been above mentioned. That the situation of misunderstanding as regards the strategic issues of reform is obvious, and it seems, the misunderstanding in the fear of a greater number of teachers and associates from the Department of designing of the domination of Bogdanović's urban concepts, which anyway also dominated in "Saopštenje" glosses, but it is also identifiable and definite in previously mentioned "Statement of the group of professors and assistants: What is going on at the Faculty of Architecture in Belgrade" dated 7 April 1971., that is, just a day before adoption of the final document on the reform of the Assembly of the working community. This statement to the public by means of the daily Politika was signed by 40 teachers and assistants, among which, besides rather imposing names such as Milorad Pantović, Ivan Antić, Stanko Mandić, Uroš Martinović, Ivo Kurtović, Mate Bajlon, and not to list them any further, also Branislav Milenković himself. 
This action would not affect the decision of the Assembly primarily due to the circumstances of self-management-political order of the managing bodies of the Faculty in which the students participated, as well as the employees regardless their scientific or teaching positions and competences.

Finally, at the end of the publication, in the special issue of "Saopštenje" the entire work on the reform of the Faculty of Architecture in Belgrade was sublimated. Along with already cited editorial, this bulletin consists of tree parts: "What is the new school of architecture?" (obviously the text of the conclusions of the Tripartite Committee, author's comment), "Fundamental principles and structural elements which the Tripartite Committee of the Assembly of the working community of the Faculty of Architecture arrived to" signed by Bogdan Bogdanović in the capacity of the Committee Chairman and the text by Oskar Hrabovski: "The possibilities of interaction of the economy and the New school of architecture of the University in Belgrade".

The first text was elaborated into two parts. In the first one, entitled "General principles of the New school of architecture" which started as the mentioned initial proclamation of "Saopštenje": "The New school is the school of high ethical and scientific standards", is reminiscent of the strict opposition "to relatively narrow frameworks of the tuition to date". "The school is open to life, to experience and achievements of practice, science and futuristic...". In the first part of the text it was insisted on: 1. Openness of the school (previous citations); 2.Tuition process (as) the joint work of the teachers and the students; 3.Self-management relationships (equality in relationships, particularly in teacher-student relationships, author's comment) and 4. Scientific work ("University tuition process and introduction into methods of the scientific work represents an inseparable unity").

Under "The special characteristics of the New school of architecture, being the second part of the answer to "What is the New school of architecture" the following theses were provided: 1 . The approach from the general to the special; 2. Teamwork of the students and teachers - tutorship; 3. Tuition diversification; 4. Terminological elements of tuition; and (as some type of conclusion, under 5.) the proposal under the title "So that the New school would always be new...". ${ }^{4}$ 
In his text, after the editorial, Bogdan Bogdanović presented 22 positions which I will not present in full but descriptively, and under the sub-heading: "The positions which can be deemed refined and which are proposed to the Assembly to adopt them in full". This part of the text starts with the position (under 1.): The future New school should start from the study of the integral "environment" towards the special issues of architectural sciences". Further on he concluded how prequalification of knowledge was necessary, the transition to:"...inter-disciplinary, namely trans-disciplinary cooperation..." with other educated and scientific institutions, "diversification...due to the ideal pool of knowledge which exceeds by far the possibilities of the up till then regular education...", building of the principle of organization of work as the individual, teamwork and joint work of the teachers and the students, introduction of the tutor work, building of elective courses within the field of specialization, "securing the jobs for each student", along with series of formal organizational principles through the positions on duration of tuition, selfmanagement, creation of the legal basis for functioning of the New School, etc. Besides, in the part of the text "Attempt at Concretization" he mentioned also two models of concretization of positions, one proposed by the Department of designing and one proposed by the Club of the young architects.

This Bogdanović's Conclusion with 22 theses was adopted on 8 April 1971 by means of acclamation by the students, teachers and non-teaching staff at the Assembly of the faculty working community. ${ }^{45}$

Thus the reporting of the bulletin "Saopštenje 1970-71" was also concluded as well as its entire substantial contents. Through established "parity work groups" (on which the report was made following Bogdanović's text) for tuition, for liaison with economy and for self-managements, the work on the reform of the New school progressed (however, not so publicly, author's comment). The author of this text did not study the work of these work groups, until the possibility that within the school year 72/73 the amendments and realistic scopes of the reform be determined. They were, in the nature of things, principle and at the trail of the adopted conclusions, however, without the possibility to carry out the literal implementation of the activities designed in "Saopštenje". Along with that, there came to the changes in the very management bodies of the faculties, and within the faculty conflicts in respect to the reform already escalated making the consequent proceeding of the process of reform presented in "Saopštenje" impossible. 
The citation from the editorial reads: "Saopštenja -Informative notes which were primarily conceived as a type of some better or better laid out typed records, in time became more and more comprehensive and showed the tendency to develop into a scientific-theoretical periodical dedicated to the issue of architects education. It is well know that such publications exist in the world, however, their publication requires specific efforts and special expenses. It could be, that these present modest Saopštenja_ may in the future New school become one such means of information, through which, same as until the present, however, in the intensified form and with the full assistance of the professional and cultural public, the School will continue to develop its pedagogic concepts... Should later on Saopštenja become a regular publication, we would repeat many of these "glosema-glosses" in extenso, since they represent undoubtedly valuable theoretical efforts. Generally speaking, it could be stated that even the already published contributions, as well as the unpublished ones in the possession of the Tripartite Committee, testify of an extraordinary contemplative and theoretical potential, first of all, of our younger professional forces, which the Old school not only did not count on, but, could be, even put them off."

On the form of so-called "Assembly of the Working Community" see in the Constitution of the Socialist Federal Republic of Yugoslavia of 1963 (review done at: http://sr.wikisource.org/sr on 15.02.2011). 
"Tripartite Committee", or so-called "Board for the New school" was "established at the Meeting of the Working Community of the Faculty of Architecture on 7 November 1970. The name "Tripartite" corresponds to the forum in which three groups of stakeholders in the reform process participated: "the Board consists of the equal number of teachers, students and junior architects from practical work (the former students of the Faculty of Architecture in Belgrade)". This composition of the so-called Tripartite Committee was stated in "Saopštenje" No. 1 of 20 November 1970.; Within "Saopštenje" the reports from the total of 17 meetings of the Tripartite Committee are recorded, inclusive with the no. 12 of 22 March 1971., however the author's presumption is that the number of meetings was significantly greater and that they even took place after the 17th meeting from which the last report was provided.

"Glosem -gloss" (Greek $\gamma \lambda \omega ́ \sigma \sigma \alpha$ language,), unclear or word which needs interpretation; that very


purpose of explanation to be added to some text of notes, annotations, to make glosses; explain, interpret ..." (According to: M. Vujaklija, Leksikon stranih reci i izraza (Dictionary of foreign words and expressions) Prosveta, Beograd), according to the same dictionary the interpretation of the word glossator is also interesting... in the Middle Ages: the Bologna interpreters of the work Corpus juris civilis (author's digression); also "glossa Greek 1. explanation, interpretation of insufficiently known words in the scientific texts; 2. concise leading principle..." (according to Lj. Micunovic, Savremeni recnik stranih reci (Contemporary Dictionary of Foreign Words), Knjizevna zajednica Novog Sada, 1988)

See among others: Politika, special issue no. of 03.04 and 07.04.1971., Belgrade; a larger number of polemical texts in NIN weekly magazine (Weekly informative newspapers), 1970-1971., Belgrade. A series of polemical texts published in the newspapers Komunist, particularly in the period from 04.03 till 22.04.1971.; in Novosti of 30.03 and 04.04.1971, Belgrade; as well as Bilten univerziteta u Beogradu (The Bulletin of the University of Belgrade) no. 11 dated 1971; Journal Arhitectura Urbanizam (Architecture Urbanism) follows the progress of reform from the first text: T.J. Movement of the New school: The Reform at the Faculty of Architecture in Belgrade, no. 61/61, pp.127-128,; The Association of the Architects of Yugoslavia and Federation of Urbanists of Yugoslavia, 1970, Belgrade.

Mladenović, M., Likovno obrazovanje i vizuelna istraživanja na Arhitektonskom fakultetu u Beogradu (Art Education and Visual Studies at the Faculty of Architecture in Belgrade), the study at the pages.161-207. in monograph: Pavić, B., Jelenković, D., Mladenović, M., Audio-vizuelna istraživanja (Audio-Visual Studies) 1994-2004., Arhitektonski fakultet Univerziteta u Beogradu, 2008., Beograd

B. Bogdanović became the Dean of the Faculty of Architecture in Belgrade in the school year 1970/71 and replaced the present Management under the deanship of Prof. Stanko Mandicć with the vice-deans Prof. Anka Stojaković and prof. Djordje Zloković. On 9 March 1972 Prof. Branislav Milenković entered his duty of the Dean, and already in the school year 1973/74 to have Prof. Ranko Trbojević elected to the position of the acting dean. These expeditious removals of deans of the Faculty of Architecture from office point out to the significant turbulences within the institutions and that being particularly in respect to the concept of reform like Bogdanović attempted at implementing. It is interesting to note that Bogdanovićs vice-deans were assistant professors being Assist. Prof Dragan Ilić and Assist. Prof. Oskar Hrabovski, as the young teachers (it was in principle that through the bulletin "Saopštenja " the significance of the junior personnel, the students of architecture and young graduate engineers of architecture, was apostrophized) .

At the time of commencement of his deanship at the age of almost 49, Bogdanović was fully realized and very productive author just before the election to the permanent membership of the Serbian Academy of Sciences and Art (SASA), together, among other candidates, with Dobrica Ćosić and Miodrag B. Protić (see for ex. the text in the Cultural section of NIN no. 1011 of 1970 , on page 35: "In Front of Academy Doors"). His strong contacts with the political and social elite of that time were accentuated on several occasions, and his most significant public function related to the position of the Mayor of Belgrade which he performed in the period 1982/86.It is obvious that 
the issues in respect to his election or his withdrawal from the election into the regular membership of SASA (the sources speak in different manners on these circumstances, author's comment) did not influence the essentiality of his social political or artistic role, and thus this circumstance relates also to the condition following giving up the reforms of so-called New school by the teaching staff of the Faculty of Architecture.

The most concise survey of the interdependence of the artistic, scientific and socio-political profile of B. Bogdanović is provided by Prof. Miloš Perović in his Serbian Architecture of the $20^{\text {th }}$ Century (Miloš R. Perović: Srpska Arhitektura XX veka: od istoricizma do drugog modernizma (from historicism to another modernism), Faculty of Architecture in Belgrade, 2003), which caused significant polemics in the Serbian professional public following the publication. With the obvious tendentiousness of the publication author in insisting on Bogdanović's artistic and political ideology of so-called socialist estheticism, it cannot be denied that Perović was the first and the only one for now, who scientifically managed to compare the values of Bogdanović's actions, placing him within the context of another two important authors of that period: arch. Mihailo Mitrović and academician arch. Ivan Antić. That such type of characteristic insights was not a solitary one either at the time of "Saopštenja" publication and the reform of the New School is testified also by "The Statement of a Group of the Professors and Assistants" (The group of teachers and associates, What is Going on at the Faculty of Architecture in Belgrade, Politika, Wednesday issue, 7 April 1971) in which the issues of realization of the reform were discussed and in which, against reservations that the reform was imperative, Prof. Bogdanović was directly criticized (Citation "Under the parole of avant-gardism we cannot accept the practice of refutation and causing pressures, and neither to present to the public the twisted image of the condition at the faculty" (example from the Statement highlighted by the author). Further on, it is surely that interesting comparisons in respect to this issue can be found, out of which the author highlighted the one which concerned the general survey of that time of an eccentric (ultra-leftist or liberal) intellectual such as was for ex. Milovan Djilas in the monograph (pamphlet, author's comment) by D. Marković, S. Krzavac, Liberalism: From Djilas till Present, volume 1 and volume 2, publisher Sloboda, the Kompas book collection, Beograd, 1978.; Generally speaking, Bogdanović, both from the position of his cultural, socio-political, and even artistic viewpoint represented a controversial personality, untypical for the cultural and social structure of that time and this controversy will accompany him till the end of his life, conclusive with his conflict with the political elite under the leadership of Slobodan Milošević which affected his de facto exile to Vienna.

10 Toma Džadžić, Profesorska zavera cutanja - Professor's Silence Conspiracy (with the subheadline "Conflicts"), NIN, No. 1032, p. 16, dtd. 18.10.1970, Belgrade; Bogdan Bogdanović, Arhitektronski krug kredom - Architectural Chalk Drawn Circle - (with a sub-headline "Society"), NIN No. 1033, pp. 12-13, dtd. 25.10.1970., Belgrade

11 In the above mentioned text Bogdanovic challenges "revolutionary aspect" of reforms passed considering them to represent only "the reconstructions " of the existing condition", primarily with an intention that it (that condition, author's comment) is at any cost preserved." and advocates for the detailed reconstruction of tuition. He criticized the concept of "compressing" the tuition believing that the compression represented "compression of mind" and that tuition should be broadened to "a completely new, open schemes of courses, groups of courses, fundamental and specialized courses, departments and post-graduate courses". Due to the expected scope of "broadening" such tuition should be "diverssified" since "In our country there are no longer the designers of general practice, general education." He criticized the so-called "atelier type" system of tuition since "the ateliers" were "the most reactionary possible form of architectural tuition (making the students linked to the subjective interpretations of one single professor by the side of whom the student passed the greater part of the time at school and who he depended on completely, and who he could not even elect at his own option!" In "ateliers" according "to the definition... any, even the rudimentary research work was impossible." a "...the students were looking for the scientific forms of organization of designing and designing-research work". Also, "The atelier's ideology deems publishing the works and the results, writing the books, dissertations and 
professional essays, as a negative qualification", and that "Doctor's theses were prepared only by the failed architects." Bogdanović believes that "Idiosyncrasy towards the written word, which has been imposed on the entire collective" was in practice, (and) is passed on to the students as well. They (the students) make catastrophically little use of literature and books."; Qualitative presentation of the syllabuses from the field of architecture and urbanism in the SFRY and abroad prior to commencement of the 1970 reform was provided in the thematic issue of the journal" Arhitektura Urbanizam: Jugoslovenske skole urbanizma, (Architecture Urbanism, Yugoslav Schools of Urbanism), no. 52, pp. 27-75, Savez arhitekata Jugoslavije i Urbanisticki savez Jugoslavije, (Association of Architects of Yugoslavia and Yugoslav Federation of Urbanists)1968, Belgrade

citation: "In June, 1968 at the assemblies of the Faculty of Architecture it was proclaimed that the formation of one NEW SCHOOL would immediately begin which should replace the present traditional and overly obsolete (superseded) professional and scientific status of the Faculty of Architecture. Since the new school have not been formed to date nor has any more serious effort been made to proceed with its formation, today's Assembly elects a special BOARD FOR NEW SCHOOL,..., which is entrusted with the task to urgently start with preparation and elaboration of one new structural scheme of the future Faculty of Architecture and to submit to the Assembly its proposal for adoption, rejection or amendment by the beginning of April, 1971..."

In the interview given to Milan Milošević in 1992 under the headline The Impetuses of the Heated Imagination, the reprint of which was published in Belgrade magazine Vreme No. 96, in the section The Collocutor of the Age, Bogdanović, speaking about his former friend, the academician Dobrica Ćosić, the President of the state at that time, answers the question "When did your friendship "break up"?" literally: "When I returned from the States, we initiated the New school of architecture. The New school of architecture was a sort of the Red faculty in accordance with the contemporary spirit of the time. It seems that the liberals supported us. Being "The Red Dean" I was not liked by my new academic society, the society of hierarchy."

Within this context it is essential to perceive the position of Marko Nikezić, the most important political leader in Serbia at that time. Marko Nikezić was the architect as per education, and in the period between 1968. and 26 October 1972., held the function of the President of the Central Committee of the League of the Communists of Serbia. It is also significant to note the fact that before this mandate he held the function of the Federal Secretary of Foreign Affairs. Within this context, it is inconceivable that the contemporary dean of the Faculty of Architecture and the corresponding member of the SASA, B. Bogdanović, had no significant contacts with Nikezić. Also, both of them shared the war biography in the NLM (National Liberation Movement) as well. Coinciding of Nikezić's and Bogdanović's biographies reflects also upon the facts that both of them were removed from their functions during 1972., when Nikezić, together with Latinka Perović, was accused of so-called anarchic-liberalism. Following these removals, Bodanović's political career was not directly and fully terminated, until the famous Eight Conference of the LCS (League of Communists of Serbia) at which Bogdanović stood up to the politics of Slobodan Milošević.

See citations with the comment in the mentioned publication: Branko Pavić, Dragan Jelenković Milorad Mladenović, Audio-Visual Studies 1994-2004., Faculty of Architecture of the University of Belgrade, 2008., Belgrade and particularly the text: M. Mladenović: Visual art education and visual studies at the Faculty of Architecture in Belgrade, the study, p. 179 of the monograph, in which Action program of the Basic organization of the League of Communists of the Faculty of Architecture in the Fight for realization of the New school was mentioned, as an undated archive document. It is obvious that this document was presented before the very realization of the program of the New School in the school year 1972/73, since it incorporated practically all conclusions of the Board for the New school presented in the archive document under the title Fundamental Substantial and Structural Elements of the New school which the Tripartite Committee of the Assembly of the working community of the Faculty of Architecture in Belgrade arrived to passed at "the last, extraordinary meeting" on 2. April 1971, and which was signed 
by the Chairman of Tripartite Committee, arch. Bogdan Bogdanović. It is characteristic that also in the Action program of the BOLC (Basic Organization of the League of Communists) the obligation of realization of the initial concepts of the New school of 1968 was mentioned, as well as a whole series of instructions for action of the communists at the faculty, their ideological work and particularly on the postulates 7,8 and 9 in which it was insisted on active and true engagement of the communists: from the activities on the active and reliable action of self-management bodies as far as the requests for more significant treatment within the sphere of Marxism education at the faculty. Other postulates fully correspond to the newly proclaimed concepts of the New school published in the mentioned document of the Tripartite Committee. All official documents of the Faculty of Architecture from that period have been field under the file number which refers to the intra-faculty minutes from the meetings and official correspondence from the subject period have been archived in the Historical Archive of Serbia.

The political status of the socialist self-management is colored in "Saopštenja" primarily by advocating for complete and continuously proclaimed equality of the stakeholders in tuition: the students, professors and associates, and being first of all through the scientific-research process of tuition and possibility of students' choice of elective structure of syllabus, freely formulated scientific-research procedures through orientation and elective courses. This leads to conclusion that constant proclamations on equality of the stakeholders of tuition in "Saopštenja" were rather the expression of the interest of the reform-minded teachers and that with the assistance of the "progressive" youth and their reform-orientated energy would come to the change of the syllabus, than that behind this synergy there was a particular political intention in accordance with the self-management tendencies of that time. In the meantime, a significant public discussion was underway in public on the self-management relationships at the faculties in which as dominant questions the following were asked: : Are students the working people at the University?". "Is the University the organization for the production of science?", and even also "Do students have to be paid for their work at the University?" As regards these questions see: Mirko Klarin, Reforma u procepu nepoverenja, (The Reform in the Tight Spot of Distrust), NIN, No. 1032, pp.16-17, dtd 18.10.1970, Belgrade "Saopštenja" No. 12 dated 22 March 1971, the gloss 100, pp 128-130;

Associate professor Bozidar Petrović by his narrative in the annex to the mentioned "Conclusions" (see above in the analysis of the text of "Saopštenja No. 1 p.3), and in respect to "planning the future school" provides "some summary predictions of the development for the coming 10-15 years..." through imperatives which one had to start from in the reform: "- to establish much better communication between the machines and the man; -The increase of the power of memory of information goes as far as infinite. (Presently the machines are manufactured which will abolish the notion of the library in the present sense of the word); - Many positions and professions will be cut. It has been assessed that $50 \%$ of professions will be cancelled, on the basis of automatization and will be replaced by other ones which will relate to managing the concepts of creative actions and machines control; - Every seven years the human knowledge will be doubled at least in the first phase; - Each present day young man will be forced to change the character of his/her profession at least three times during his/her life; - Almost complete prefabrication and industrialization in building industry; - Completion of the procedure of integration of economic organizations within the form of large systems; - In one place he says: "In contemporary school if we really want it to be the school we have to approach the students with an objective image of the world, to prevent their alienation from the world of events and thus enable employment of the young architects," and further on: "...And we should fear the fact that the young people will be more heard about abroad than at home." In "Saopštenje" No. 2 at p. 7. Dusan Krstić, B.SC.Eng. stated in the text The Issues of Architectural Education : that "it can be considered as a common and the biggest drawback, ...the lack of teaching the latest architectural theory." And that " The level of the theoretical engagement of the architects are intolerably poor." It is interesting that already then he realized that the theories which originated between 1900. and 1930. were no longer sufficient, and for the generations "which will emerge in a quarter of the century's time" they would have yet 
a lesser value (the mentioned modern theories remained basic in education of architects to date, author's comment)

Following the above mentioned note, Krstic stated that it was obligatory to "pay great attention to better preparation of the students for actual practice in order to avoid the tragic moment of misunderstanding and gross clash with reality at the beginning of work..." In the gloss 23 (p.61 of "Saopštenje" Dragan Jovanović refers to "Self-regulatory system of orientation of the syllabus" along with the citation of the part of the text " The economy alters the syllabuses of the faculties" from the daily Politika dated 11.1.1971. of Studies in the New School was published. At the pages 53-58 Mušić refers to the conclusions of R.I.B.A. researches and stated that with the absence of "diversification" the conservatism of the university institutions was preserved. "Fetishism of inter-discipline" is associated with "multiple amateurism" and he opposed the notion of "trans-discipline" to that. Mušić refers to the experience in the States and in England where at numerous faculties successful specialization was implemented and within that context mentioned: regional spatial planning, urban planning, landscape architecture (landscape regulation) and industrial shaping ("design") . "We are asking from them (the students, author's comment) to be educated persons, able to universally, globally perceive architecture as an element of integrated environment. We are finally asking them to say or write something on all that, and at the highest professional level. Unfortunately, there is no personality at our present time, there is no individual of our kind which could pass through all these requirements of such education, without facing the danger of spiritual and even intellectual collapse... The old concept of "a complete architect" is a dangerous anachronism. " citation." Completeness of an architect" he opposed to the notion "... of the universal... who (exclusively, author's comment) complied with the system of social ethical standards and the system of values, the same way he complied with the scientific method of work...Each, and the slightest problem has to fit into a universal concept of the environment."

More than indicative is the text of the editorial report published in Politika, Wednesday issue of 7 April 1971, on pages 5-6 from the Conference of the Serbian Youth Union, which the entire narrative of Marko Nikezić is added to. This confusing report under the title "Orientation towards oneself is neither shutting nor giving up the responsibility for the development of the opportunities in Yugoslavia" notes more significant insistence of practically entire Serbian government top people on acceptance of the role of Serbia in the future constitutional system than it insists on the issues of position of the youth and its education in respect to future constitutional amendments. Only briefly, in the capacity of the re-elected Chairman of the Presidency and Secretariat of the Republic Conference, part of the speech of Miroslav Marković was interpreted saying: “...that the youth organization rightfully focused on the issues of the worker's young generations and the working youth, on the human resources reconstruction of the economy and the fight for selfmanagement school. Because, the young are discontent with the slowness in establishing the country human resources requirements, in reforming the syllabuses and systems of education in general and the space for self-management which till then was won by the young generation." The text incorporates also few significant comments of Janez Kocijančić in respect to a great number of workers abroad, however in the further narratives it was stated that the number of experts leaving to work abroad was small ("only 1 percent") and that the local economy had great demand in educated staff. Nikezić in his narrative insisted on more active action of the youth through the membership in the Communist League in order to have the topical problems resolved, and the greater part of his narrative was devoted to the issues of national politics in realization of the new Constitution. It was already the following day, in Thursday issue of Politika, of 8 April 1971, in the editorial report from the meeting of the secretaries of the faculty committees and the members of the University Committee of the SLC in Belgrade, under the title "There is no Fight against Nationalism with a Meter in Hand" citing dr. Branko Pribićević, the discussion held was fully devoted to the issues of nationalism and it was only briefly stated how “.... at the present public discussion,...the students at the faculties, where such discussion was held, showed great interest 
in constitutional amendments. The general impression is that at all those gatherings the changes in political and economic system were given full support, and the necessity to do so expressed." Rather qualitative analysis of the condition at the University, and particularly in the light of legal regulations and general reform endeavors in enactment of the new legal frameworks of education were presented in detail in the text: Mirko Klarin, Reforma u procepu nepoverenja, (The Reform in the Tight Spot of Distrust), NIN, No. 1032, pp.16-17, dtd 18.10.1970, Belgrade. This text particularly highlights the issues of relationships between the students and various University institutions (first of all the University Council) as well as the descriptions of the broad students requests for reform (in line with the ideology of self-management, author's comment). The text also deals with the parallels with the conditions at other Yugoslav universities.

Testimonies on the link of the New school to the Students' Cultural centre and accordingly to the artists' groups which simultaneously pursued their activities there can be seen at: S. Maldini., Arhitektura Novog pokreta u Beogradu u periodu 1970-tih-1980-tih (The Architecture of the New Movement in Belgrade in the period of the 1970s and 1980s) at internet edition at the page: http:// maldinis.blogspot.com, text dated 24 December 2007. (survey dated 21 March 2011)

One should not disregard the continuous proclamation "The school is open to life" which runs through the numerous documents "Saopštenje ", and which was substantially taken over from the basic postulates of all neo-avant-garde art and philosophical movements which emerged following 1968. and at the beginning of the seventies. This suggestion was also provided by Aleksij Brkić in his work Znakovi u kamenu (The Signs in the Stone): Srpska moderna arhitektura 1930-1980, (Serbian Modern Architecture 1930-1980), Savez Arhitekata Srbije (The Association of the Architects of Serbia), 1992, Beograd

"Yet, since the seventies the outside world has started to affect the laboratories and seminar rooms in a more direct, however, also more powerful way, by means of the revelation that technology based on science, and its power multiplied by the global economic explosion, seems to create the fundamental and maybe irreversible changes on the planet Erath, or at least on the Earth as the living organisms habitat. It even stirred the spirits more than the prospects of the nuclear war catastrophe which obsessed the mind and imagination of people during the long Cold war; since the Soviet-American war could have been avoided, and as it turned out, it was avoided. It was not so easy to avoid the by-products of the economic growth associated with science." Citation Erik Hobsbaum, Doba ekstrema (The Age of Extremes), p. 414, Dereta, 2002., Belgrade Ibid, p.393: "There was maybe a total of eight thousand persons altogether consisting of all British and German physicists and chemists in 1910. At the end of the eighties the number of scientists and engineers actually engaged in the researches and experiments amounted to about five million in the entire world...their number continued to increase dramatically, doubling more or less in twenty years following 1970, even in the most developed economies. Till the end of the eighties they formed the peak of much larger iceberg of that which could be called a potential scientific and technological manpower, in which the educational revolution of the second half of the century was reflected..."

In "Saopštenje" No. 10 dated 3. February 1971. (pp. 72-75) Predrag Zrnić provides a number of "Answers to the questions asked in the poll." An impression cannot be avoided that the presented answers were selected tendentiously (66 answers from the poll for the individuals (architects) from the group of about 540 possible answers given that 5 questions in the poll relate to the questions of interest for the tuition reform, and that the other entries in the poll were personal information on the polled individuals and that the total of 108 architects participated in the poll). On the page 77 there is an analysis under the title "The Results of the Poll" in which significant advocating of the polled for "diversified" tuition was stated and interesting proposals presented on the new subject matter of interest for research at the Faculty of Architecture, as well as a great number (16) of the proposed various profiles of architects (specialists) which could be educated at the Faculty. It is understood that this poll cannot represent the extract from the representative sample, however, for the present day reader the very strategy of polling is important and the attempts that the polled and non-polled public be orientated towards the interests proclaimed in the reform 
It was already in my text (see footnote 6) that the general comments were provided on reform process thus implemented the basic postulate of which was the belief that the methodology of the New school reform and the work of the Tripartite Committee gave rise to almost boundless set of scientific, theoretical and economic interests, and that from such methodology all these interests cannot be implemented in the concise, consequent and optimal syllabus and program. Naturally, it is another issue what is the importance of the proclaimed postulate "The Approach from the General to the Specific" from " The Studies on the Substantial Elements of the New school..." (p. 3. of the special issue of "Saopštenje"), which starts from the presumption that only from the sense of the activity of architects and the complexity of practice of the architectural profession in the new conditions of "the integral environment" it is possible to arrive to the justified syllabus and program. The scope and disperse quality of "the Catalogue of the Required Knowledge" will certainly bring the entire Faculty, and even the public, back to rather practical issues of reform, because of its dispersed material and its factual uselessness, and also impossibility of implementation, and that especially given the capacities of teaching staff and their qualified and scientific abilities which are essentially dependant both on the social and also on the historical conditioning of the development of an institution such as the Faculty of Architecture in Belgrade


secret political association, established in 1780 in Romania by the poet Riga od Fere and which was renewed in 1814 in Odessa, the goal of which was liberation of the Greeks and other Balkan Christians from the Turkish rule (according to M. Vujaklija., Leksikon stranih reci i izraza, Prosveta Beogard)

The formulation from the meeting is interesting stating that "the teaching departments...will be replaced with standing work teams of teachers and students (whereby) they acquire the character of the research units." along with a brief description of their activities from compiling the information as far as "The major information center of the faculty"

"Let us at the bottom of our awareness be convinced that we are facing a new and different approach to the world in which we live. It is not the world from our images like we used to accept at our younger age. It is not the world of Newton and his determinants which ruled until yesterday and which we were educated on. That world has collapsed in the heads of all active intellectuals of the present day. In its place there came the exciting world of Heisenberg and it runs by a fantastic progress, confusing and unfathomable.." (citation. Arch. Boža Petrović, Ssavremeni pristup školi (Contemporary Approach to School) p. 3 "Saopštenje"). See also in respect to this the comments in gloss 20 of arch. Ranko Radović ("Nova škola arhitekture - zašto? (The New school of architecture - why?), pp. 71-72, "Saopštenje")

More than obvious is the influence of the thirty years earlier developed scientific discipline of cybernetics (by the creator Norbert Wiener) which developed through specific fields such as: theory of information, theory of coding, theory of formal languages and grammar, theory of games, mathematical logics, theory of algorithms and programming, robotics, etc. (the list of disciplines downloaded from internet portal Wikipedia

Oskar Hrabovski, Industrijsko gradjenje - modul i metal (Industrial construction - module and metal), gloss 15, p. 45 of "Saopštenje" Lohse Richard (Zurich) gloss 16, p. 47. of „Saopštenje“

Inevitable is the impression that the entire philosophy of the New school is brought down to the meaning of the words of Claude Lévi-Strauss formulated in 1988 as the answer to the question: " Do you think that there is place for philosophy in the present day world": "naturally, there is, but only if it is based on the current state of scientific knowledge and achievements...Philosophers must not be isolated in respect to the science. The science has not only broadened and transformed our view of life to a great extent: it has also revolutionarized the rules according to which the mind acts." (Citation taken from Erik Hobsbaum, Doba ekstrema, (The Times of Extremes) p. 393, Dereta, 2002, Belgrade. 
that among them there were certain differences in the manner of presentation (the layout of the chart, for example, somewhere it was from the left to the right, somewhere top-down, bottom-up, etc.,,, and the differences existed also in the very semiotics selected.": (citation, Report form the fifth meeting, Saopštenje N. 6) or "...the first results of "breaking down" undoubtedly indicate that the New school would look for the fundamental forms of its structure in one numerous possibilities of diversification. However, so as not to betray the adopted methodology ...(in) preparation of the organizational-tuition charts of the New school, the (charts) will not be addressed ad hoc but the variants proposed, will be studied, one after another, or in parallel. A group of mathematicians was asked to monitor this work and to assist in analysis in their own way by establishing, as much as possible, the common terms of evaluations for comparing the charts proposed." (citation, The report from the eight meeting, Saopštenje No. 9). The citations speak about all that importance to subsume the enormous scope of the proposed tuition material under a unique and easy to read program, authors comment.; School book, 72/73, Faculty of Architecture, Belgrade, 1972.

"the common belief is, however, that the first next task was defining the syllabuses, and not making organizational charts. The organization of work at the faculty will only depend on the syllabus. (citation, B. Otašević, see note 38 )

Literal translation of this figure reads: "In $<$ the six wheels car $>$ which is presented here there are illustrative charts of different Kabbalah" (translation J. Tolic);

That certain Kabbalah or Masonry characteristic of the publication is not yet one type of Bogdanović's sheer and abstract estheticism of the play of symbols can be read through several layers. One of them can be undeniable comparison to the elements characterizing the Mediale movement (see for example the emergence of "the mystic Baltazar lodge" in 1952., which preceded the Mediale, a powerful influence of the texts of Borhes, Berdjajev or Elijade upon the group through the mediation of Sheika, a significant influence of Christian mysticism (Pedja Ristić, Milić Stanković, author's comment). The next layer certainly lies also in the very spiritual interests of Bogdanović's (see former notes) and in the entire systematization of his actions and methodology of artistic creation which will not be further discussed in this paper, however I will mention a significant polemics which started with Bogdanović's manifest text " Povratak Grifona" (The Return of Grifone) and powerful drawing of the author on the writers such as Lewis Carroll (see: B. Bogdanović, Return of Grifone (sketching heuristic play as per the model of Lewis Carroll), The Third Symposium on Synthesis of the Art: With the Sketch Towards Synthesis, Cultural Propoganda center, Vrnjacka banja, 6-14-1 1978, as surely representative manifest text published 7 years after the reform of the New school). Interesting casual comments on Bogdanović's mysticism" are provided by Aleksej Brkić in the monograph Znakovi u kamenu (The Signs in the Stone) (Serbian Modern Architecture 1930-1980), Savez arhitekata Srbije, 1992, Beograd; One of the layers certainly represents the model or the concept of "city building" which the author emphasized in his text (see the source in the notes). According to his own statement in the interview at B92 TV the interest for the Jewish mystical literature was shown by Bogdanović since his first significant work., The Monument to the Jewish Victims of Fascism dating 1951 at the Sephardic Cemetery in Belgrade; similar mysticism in monument building can also be followed in Bogdanović's descriptions of methodology and philosophy of the work at Slobodište in Kruševac, which later on was commented by already mentioned Petrović.

From a greater number of informal interviews the author of this text became convinced of the significance of the entire hippy movement not only upon the social climate of that time, but also upon the very intentions of realization of the New school of (architecture). "The students felt that the New school would bring about breaking free from institutional formalism of the University, the freedom of action and freedom from the rigid school vices. Football was played in the Faculty corridors..."

"... it is necessary that one separate parity school body on the professional basis, and at the same time liaised with the public, continues with constant study of the development of the schools and the requirements of contemporary science and practice. With timely intervention of that body 
in the teaching process we will not allow the school to become outdated and to be cocooned in the forms which do not follow the continuous social progress." (Page 5. of the special issue of "Saopštenje")

See comment on this event: B. Otašević, Nova arhitektonska škola (New school of architecture), Politika of 9. April, 1971, the Cultural section, Belgrade: "At the entrance into the amphitheatre, under the wreath it was written: "The old school is dead. We deeply mourn it had not died earlier" (Citation, Otašević), also, by the same author: "Tripartite Committee, which at yesterday's assembly practically completed its task, will most likely withdraw from the function. Since its meetings have attracted great attention of the public, not only the students' one, but also wider, it has been decided that every Friday the discussion on architecture would continue"

Tripartite Committee of the Assembly of the working community of the Faculty of Architecture (Tripartritna komisija Zbora radne zajednice Arhitektonskog fakulteta), Saopštenje 197071: collection of bulletins 1-14. with the special issue, Arhitektonski fakultet Univerziteta $\mathrm{u}$ Beogradu, 20.November 1970.-8.June 1971., Beograd

Mladenović, M., Likovno obrazovanje i vizuelna istraživanja na Arhitektonskom fakultetu u Beogradu (Visual Art and Visual Studies at the Faculty of Architecture in Belgrade), study at the pages.161-207. in the monograph: Pavić, B., Jelenković, D., Mladenović, M., Audiovizuelna istraživanja (Audio-Visual Studies) 1994-2004., Arhitektonsi fakultet Univerziteta u Beogradu, 2008., Beograd

Perović, R.M., Srpska arhitektura XX veka : od istoricizma do drugog modernizma (Serbian Architecture of the $20^{\text {th }}$ Century: from historicism to the other modernism), Arhitektonski fakultet, 2002., Beograd

Group of authors, University tuition of architecture in Serbia 1846-1971 (Visokoškolska nastava arhitekture u Srbiji 1846-1971.: Unpublished manuscript, Faculty of Architecture of the University of Belgrade, 1996., Belgrade 
Brkić, A., The Sigsn in the Stone (Znakovi u kamenu):Serbian Modern Architecture (Srpska moderna arhitektura 1930-1980., Savez arhitekata Srbije, 1992., Belgrade

Hobsbaum, E., The Times of Extremes: the History of the Short Twentieth Century (Doba ekstrema: Istorija Kratkog dvadesetog veka 1914-1991, Dereta, 2002., Beograd

Arhitektura Urbanizam, journal, especially No.52 of 1968. and issues from 61-62 of 1970., Savez arhitekata Jugoslavije i Urbanistički savez Jugoslavije, Beograd

Group of authors, The School Book 72/73 (Školska knjiga 72/73), Arhitektonski fakultet Beograd, 1972., Beograd 